\author{
ks. Józef Pochwat MS \\ Kraków
}

\title{
Zagadnienie nawrócenia i pokuty w dziełach Sulpicjusza Sewera
}

Człowiek od momentu grzechu pierwszych ludzi dziedziczy skażoną naturę. Chrzest gładzi sam grzech, ale pozostają jego skutki. Dlatego chcąc żyć w przyjaźni i bliskości Boga, człowiek potrzebuje nawrócenia i pokuty. O tych prawdach wiary pisał Sulpicjusz Sewer (ok. 360-420), adwokat-mnich żyjący w Akwitanii w Galii na przełomie IV i V wieku zafascynowany osobą i działaniem św. Marcina z Tours ${ }^{1}$. Sulpicjusz, autor kilku dzieł moralno-ascetycznych ${ }^{2}$, podał w nich swoją wykładnię wewnętrznej i praktycznej przemiany człowieka według norm ewangelicznych, a ściślej mówiąc, w tej interpretacji życia Ewangelią, jaką był monastycyzm przełomu IV i V wieku w Galii.

W niniejszym opracowaniu posłużyłem się wszystkimi dziełami Sulpicjusza Sewera, wydobywając z nich treści o nawróceniu i pokucie ewangelicznej. W istniejącej literaturze przedmiotu nie spotkałem opracowań poświę-

Na temat biografii Sulpicjusza Sewera, zob. Ghislaine de Senneville-Grave, Introduction, [w:] Sulpice Sévère, Chroniques, Paris 1999, s. 7-68, Sources chrétiennes [dalej : Sch] 441; M. Starowieyski, Święty Marcin i jego biograf, „W Drodze” 11 (255) 1994, s. 63-74; Vademecum historyka starożytnej Grecji i Rzymu. Źródłoznawstwo czasów późnego antyku, pod red. E. Wipszyckiej, t. 3, Warszawa 1999, s. 196-198; J. Pochwat, Sulpicjusz Sewer i jego dzieło w czasie przemian dziejowych w Galii na przełomie IV i V wieku, [w:] Starożytny chrześcijanin w obliczu przemian dziejowych, pod red. B. Częsza, Poznań 2011, s. 65-102, Teologia Patrystyczna, t. 8.

Dzieła Sulpicjusza Sewera: Dialog pierwszy; Dialog drugi; Dialog trzeci; List pierwszy do Euzebiusza; List drugi do Aureliusza; List trzeci do teściowej Bassuli; Chronicorum libri II; Vita S. Martini (Żywot św. Marcina). (Tłumaczenie tekstów z Kronik jest własne, dlatego w przypisach podaję tekst oryginalny). 
conych zagadnieniu nawrócenia i pokuty w ujęciu adwokata z Bordeaux. Temat artykułu został opracowany w dwóch punktach: 1. Nawrócenie i przebaczenie i 2. Pokuta.

\section{Nawrócenie i przebaczenie}

Sulpicjusz Sewer komentując Stary Testament, zwrócił uwagę na liczne grzechy mieszkańców Niniwy, do której Bóg posłał proroka Jonasza, i na potrzebę ich nawrócenia do Boga. Jonasz nie chcąc wykonać polecenia Boga, uciekł na statek, jednak Bóg nie pozwolił na lekceważenie Jego polecenia i Jonasz został z okrętu wyrzucony. Uratowany przez potwora morskiego wrócił do Niniwy i wzywał mieszkańców miasta do nawrócenia ${ }^{3}$. Jonasz został posłany do miasta liczącego sto dwadzieścia tysięcy mieszkańców. Ludzie z Niniwy, gdy chodzi o popełnianie grzechów, porównani zostali do

3 Sulpicjusz Sewer, Chroniques, I, 47, 1, s. 206, SCh 441 - „Celebris circa haec tempora Niniuitarum fides traditur. Id oppidum olim ab Assure, Sem filio, conditum caput regni Assyriorum fuit. Frequens tum incolentium multitudine, alens uirorum milia $C$ et XX atque ut in magno populo abundans uitiis. Quis Deus motus Ionam prophetam ex Iudaea ire praecepit ac denuntiare urbi excidium, sicut olim Sodoma et Gomorra diuinis ignibus conflagrassent. Verum propheta praedicationis istius ministerium detrectans, non contumacia sed praescientia qua uidebat Deum paenitentia populi placandum, nauim, quae longe diuersa regione Tharsos petebat, conscendit. Sed ubi in altum processum, nautae saeuitia maris compulsi, quisnam esset mali causa, sorte explorauere. Cum super Ionam sors decidisset, tamquam piaculum tempestatis in profundum proiectus est. Exceptusque a ceto, marino monstro, ac deuoratus, post triduum fere Niniuitarum litoribus eiectus iussa praedicat: urbem scilicet ob peccata populi triduo perituram”. Tłum. na j. pol.: „Istnieje słynny przykład wiary mniej więcej z czasów Niniwitów. To miasto [Niniwa] założone niegdyś przez Assura, syna Sema, było stolicą królestwa Asyryjczyków. Liczne pod względem ilości mieszkańców, karmiło sto dwadzieścia tysięcy mężów i przy tak wielkiej ilości mieszkańców obfitowało w ilość wad (por. Jon 1,2). Bóg poruszony tymi wadami nakazał Jonaszowi tam pójść z Judei i zapowiedzieć miastu zagładę, podobnie jak niegdyś Sodoma i Gomora spłonęły za sprawą ogni Bożych. W rzeczy samej, prorok odmawiając posłudze owego przesłania, nie przez upór, ale na podstawie uprzedniej wiedzy, ponieważ widział, że Bóg zostanie przebłagany przez pokutę ludu, wszedł na statek, który podążał do Tarszisz, miejsca daleko innego, niż polecono mu pójść (por. Jon 1,3). Lecz gdy wypłynięto na głębię, żeglarze uderzeni zostali wzburzeniem morza i losowaniem badali, któż jest przyczyną tego nieszczęścia. Gdy rzucili los ponad Jonaszem, został rzucony w otchłań morską jako ofiara przebłagalna dla uspokojenia burzy. Pochwycony przez wieloryba, morskiego potwora i pożarty, po trzech dniach został wyrzucony niemal przy wybrzeżu Niniwy, gdzie zaczął głosić nakazane mu przez Boga polecenia, to znaczy, że miasto zginie po trzech dniach z powodu grzechów ludu". 
mieszkańców Sodomy i Gomory, co oznacza ich wielkie zdeprawowanie. Podobnie jak Sodomie i Gomorze groziła im kara całkowitego zniszczenia. Sulpicjusz Sewer komentując te wydarzenia, zwrócił uwagę na wizję proroka, który „widział, że Bóg zostanie przebłagany przez pokutę ludu” („qua uidebat Deum paenitentia populi placandum”). Pokuta za grzechy jest nie tylko możliwa, ale też skutecznie chroni przed słuszną karą, jaką Bóg zsyła na grzeszników.

Mnich akwitański wzywając do nawrócenia, odwołał się do historii Izraelitów ze Starego Testamentu. Dla Sulpicjusza Sewera nawrócenie jest wyrazem posłuszeństwa wymaganiom Bożym. Używając tego biblijnego porównania, asceta akwitański wskazał, że niewola lub śmierć na wojnie to są konsekwencje trwania w kulcie bożków pogańskich. Grzechy prowadzą zawsze do tego samego: śmierci na wojnie albo w niewoli, czyli do jakiegoś zła.

Sulpicjusz Sewer ukazał także pewną prawidłowość: w czasach pomyślnych Żydzi skłaniają się ku bożkom, w czasie trudnym wołają do Boga. Za grzechy Bóg doświadcza swoją surowością i zarazem miłosierdziem. Nie powinien zatem nikogo dziwić fakt odrzucenia Chrystusa przez Żydów. Znamienne jest to, że Bóg nigdy nie odmawia swej łaskawości grzesznikom, którzy się do Niego zwracają, nawrócenie bowiem zawsze jest możliwe, pod warunkiem że ludzie zwrócą się do Boga z błaganiem o ułaskawienie ${ }^{4}$.

4 Tenże, Chroniques, I, 23, 3-4, s. 148-150, SCh 441 - „Rursumque Hebraeos sectantes idola rex Chananaeorum Iabin nomine subiugauit grauissimamque in eos per XX annos dominationem exercuit, donec pristinum Debbora mulier statum reddidit. Adeo nihil spei in eorum ducibus erat, ut muliebri auxilio defenderentur. Quamquam haec in typum ecclasiae forma praemissa sit, cuius auxilio captiuitas depulsa est. Sub hac duce uel iudice XL annis Hebraei fuerunt. Rursumque ob peccata Madianitis traditi duro imperio habebantur, afflictique malo seruitutis diuinum auxilium implorauerunt. Ita semper in secundis rebus immemores caelestium beneficiorum idolis supplicabant, in aduersis Deo. Vnde cum reputare in animo soleo populum tot beneficiis Dei obligatum, tot cladibus cum peccaret coercitum, expertumque et misericordiam et seueritatem Dei nequaquam emendatum, et cum semper ueniam erroris acciperet, semper peccasse post ueniam, nihil mirum uideri potest Christum ab his non receptum, cum iam inde ab initio totiens in Domino rebelles deprehendantur. Magisque mirum est, illis semper peccantibus numquam Dei, si quando eum implorauerunt, defuisse clementiam”. Tłum. na j. pol.: „I znowuż Hebrajczyków idących za bożkami podbił król Kananejczyków o imieniu Jabin; gnębił ich nader ciężko przez dwadzieścia lat, póki kobieta Debora nie doprowadziła do przywrócenia poprzedniego stanu. Do tego stopnia nie było wśród nich żadnej nadziei w stosunku do męskich wodzów, że oparli się na kobiecej pomocy. Chociaż przez to ta stała się proroczym znakiem, typem Kościoła, dzięki pomocy której odrzucono niewolę. Pod jej przywództwem albo jako sędziny Hebrajczycy żyli przez czterdzieści lat (por. Sdz 5, 31). I znowuż z powodu grzechów zostali poddani Madianitom i trwali w takim twardym położeniu, a gnębieni przez owo zło niewoli, błagali o Bożą pomoc. I tak zawsze w sytuacjach pomyślności zapominając o niebiańskich błogosławieństwach, składali błagania do bożków, w cza- 


\section{Sulpicjusz Sewer uświadamiał wszystkim wierzącym, że nawróce-}

nie do Boga uzyskuje się na drodze łaski Bożej osiąganej przez błaganie. Nawrócenie to uzyskanie miłosierdzia od Boga, a jest ono zawsze łaską Bożą. Zniewolenie, brak pomyślności stanowią oznakę, że Bóg nie jest ze swoim ludem, zaś zwrócenie się do Boga wyzwala z niewoli:

Dlatego też, gdy nad nimi - jak wyżej powiedzieliśmy - panowali Madianici (por. Sdz 6, 1), nawróciwszy się do Boga, jak zazwyczaj błagając, uzyskali miłosierdzie. Był wśród Hebrajczyków pewien mąż o imieniu Gedeon, człowiek sprawiedliwy, drogi Bogu i przez Niego zaakceptowany.Jemu, wracającemu z żęcia z pola do domu, stanął na drodze anioł i powiedział: „Pan z tobą, potężny w cnocie”. Gedeon zaś użalał się głosem uniżonym, że Bóg nie jest z nim, ponieważ Jego lud cierpi zniewolenie i płacząc, wspominał moce Boże, który ich wyprowadził z ziemi egipskiej. Wtedy anioł rzekł: „Idź w tym duchu, w którym to wypowiedziałeś i wyrwij lud z niewoli” (por. Sdz 6, 14)

Mnich akwitański przy każdej okazji wspominał swego mistrza monastycznego - św. Marcina. Ten patriarcha mnichów Zachodu czynił cuda mocą krzyża Chrystusa. W opisie Sulpicjusza znak krzyża wyzwala, daje władzę nad naturą i demonami, kruszy serca błędnowierców i daje moc wiary w Pana Jezusa. Nawrócenie jest dziełem krzyża, łaski Chrystusa i nieugiętej wiary i ufności w Bożą pomoc jego sługi Marcina. Postawa św. Marcina miała równocześnie wymiar społeczny, bowiem przyczyniała się do nawrócenia tych ludzi, którzy byli świadkami zdziałanych przez niego cudów ${ }^{6}$.

\section{Św. Marcin, jak zaświadcza Sulpicjusz Sewer, doświadczył na sobie} działania zła w postaci napaści zbójów i utraty wolności. Wydarzenia te miały

sach niepomyślnych - Bogu. Dlatego też, gdy zwykłem w duszy oceniać ten lud związany z Bogiem tyloma dobrodziejstwami, ćwiczony tylekroć przez klęski, gdy popełnił grzech, doświadczany miłosierdziem i surowością Bożą, a przecież nigdy nienaprawiony, i gdy zawsze otrzymywał ułaskawienie za grzech, a po ułaskawieniu zawsze grzeszył, to nie można się dziwić, że Chrystus nie został przez nich przyjęty, skoro już u samych początków tylekroć podnosili bunt przeciwko Panu. I bardziej jest dziwnym to, że chociaż zawsze grzeszyli przeciwko Bogu, to jednak nigdy nie brakowało łaskawości Bożej, kiedy tylko o nią prosili".

Tenże, Chroniques, I, 24, 1-2, s. 150-152, SCh 441 - „Igitur cum eis, ut supra retulimus, Madianitae dominarentur, conuersi ad Dominum, misericordiam solitam flagitantes, impetrauerunt. Erat in Hebraeis Gedeon quidam nomine, uir iustus et carus Deo acceptusque. Huic angelus de campo messis domum reuertenti astitit: «Dominus», inquit, «tecum potens in uirtute». At ille uoce humili non esse in se Deum ingemescebat siquidem quod populum captiuitas premeret, uirtutumque Domini, qui eos de terra Aegypti eduxerat, flens recordabatur. Tum angelus: «uade», inquit, «in hoc spiritu, quo locutus es, et populum de captiuitate eripe»".

6 Tenże, Żywot świętego Marcina 13, 7-9, [w:] tegoż, Pisma o św. Marcinie z Tours. Żywot, listy, dialogi, przekł. P. J. Nowak, wstęp, komentarz i opracowanie M. Starowieyski, Kraków 1995, s. 69, Źródła Monastyczne, nr 8. 
miejsce w dużym oddaleniu od osad ludzkich. W opisach owych ataków, podanych przez Sulpicjusza, można dostrzec trzy różne postawy złoczyńców. Jeden ze zbójców chciał zabić Marcina, drugi zbój go powstrzymał i związał Marcinowi ręce, trzeci natomiast miał go pilnować i obrabować. I właśnie ten ostatni się nawrócił po spotkaniu ze świętym człowiekiem, z Marcinem, który głosił mu Ewangelię i potwierdził to swoją pełną odwagi postawą:

I tak, najpierw w Alpach, idąc po bezdrożach, wpadł w ręce zbójców. Gdy jeden z nich, podniósłszy topór, wymierzał już cios $\mathrm{w}$ jego głowę, drugi powstrzymał prawicę uderzającego. Następnie, mając związane z tyłu ręce, został oddany któremuś z nich, by go pilnował i obrabował. Ten, gdy go odprowadził na bok, zaczął wypytywać, kim jest. Odpowiedział, że jest chrześcijaninem. Pytał go też, czy się boi. Wtedy Marcin oświadczył bardzo stanowczo, że nigdy nie czuł się tak pewnie, ponieważ wie, że miłosierdzie Boże najbardziej jest odczuwalne w próbach, i że bardziej boleje nad nim, który jest niegodny miłosierdzia Chrystusa, ponieważ uprawia zbójectwo. I tak podjął wykład Ewangelii, głosząc zbójcy słowo Boże. Czemuż miałbym dłużej zwlekać? - Zbójca uwierzył i udał się z Marcinem, by go wyprowadzić na dobrą drogę, prosząc go tylko, aby modlił się za niego do Boga. Widziano go później prowadzącego pobożne życie, to zaś, co przytoczyliśmy powyżej, on sam - mówią - opowiedział7.

Z przekazu Sulpicjusza Sewera wynika, że pielgrzymowanie w duchu wiary jest jedną z form nawracania się. W tekście Sulpicjusza Sewera opisana jest charakterystyczna dla IV wieku pielgrzymka wiary (peregrinatio religiosa), w którą udał się św. Marcin. Celem tej podróży była walka z szatanem, pogaństwem i arianizmem. W tym opisie można dostrzec zasadniczą różnicę pomiędzy monastycyzmem egipskim, który nie dopuszczał żadnej formy apostolstwa, a monastycyzmem galijskim nastawionym na duszpasterstwo zewnętrzne ${ }^{8}$. Wydaje się, że Marcin został wysłany przez św. Hilarego, biskupa Poitiers, zaniepokojonego rozwojem arianizmu w Illirii ${ }^{9}$.

Adwokat z Bordeaux opisał też przejawy fizycznego zła, jakiemu był poddany św. Marcin (pobicie jego i zwierząt pociągowych). Wydaje się, że fakt pobicia świętego mnicha nie ma nic wspólnego z tematyką nawrócenia. Jednakże Sulpicjusz opisując tego rodzaju wydarzenie, pomaga czytelnikowi odkryć ich głębszy sens. Pisze, że napastnicy zdawali sobie sprawę,

Tenże, Żywot świętego Marcina 5, 4-6, [w:] tegoż, Pisma o św. Marcinie z Tours..., dz. cyt., s. 59.

Por. M. Starowieyski, Poczatki monastycyzmu zachodniego, „,Warszawskie Studia Teologiczne” t. 1, 1983, s. 266 oraz przyp. 53.

9 Por. Sulpicjusz Sewer, Pisma o św. Marcinie z Tours..., dz. cyt., s. 59. 
ile wyrządzili Marcinowi krzywdy, mieli świadomość przestępstwa i grożącej zań kary. Sewer opisał też widoczne oznaki nawrócenia złoczyńców: zmieszanie i wstyd, płacz, posypanie głowy i twarzy prochem, postawę klęczącą, prośbę o darowanie winy i zezwolenie odjechania oraz wewnętrzne motywy prośby o przebaczenie: dręczące sumienie, ale i strach przed straszną karą. Marcin udzielił przebaczenia niegodziwych czynów swoim napastnikom, ponieważ widział wolę poprawy tych, którzy dopuścili się zła ${ }^{10}$.

Sulpicjusz Sewer przedstawił także postać Lucyfera, biskupa z Antiochii. Interesujące jest, że adwokat z Bordeaux nie był przekonany o słuszności lub nie przyjęcia tych, którzy po nawróceniu i pokucie powrócili do wspólnoty Kościoła. Biskup Lucyfer zdecydowanie odciął się od tych, którzy przyjęli nawróconych z błędnowierstwa ${ }^{11}$. Te dwie niejednoznaczne postawy mogą świadczyć o tym, że nie było jednomyślnej praktyki w Kościele przełomu IV i V wieku wobec osób nawracających się.

Mnich akwitański uświadamiał swoim czytelnikom potrzebę nawracania się, każde bowiem odstępstwo od Boga domaga się powrotu do Niego. Zwracał uwagę na pewną prawidłowość w historii Starego Testamentu - w życiu narodu wybranego czasy pomyślne bardziej ludzi od Boga oddalają niż zbliżają. Sulpicjusz Sewer uważa, że właściwą drogą do nawrócenia grzesznika jest postawa błagalna względem Boga. Bóg natomiast daje się przebłagać dlatego, że jest miłosierny. Miłosierdzie Boże wiedzie grzesznika ku wolności.

Sulpicjusz mając przed oczyma wciąż żywą postać swego przyjaciela św. Marcina, który toczył walkę z demonami, stwierdzał, że nawrócenie to dzieło krzyża i łaski Chrystusa. Dodawał również, że do nawrócenia może przyczynić się człowiek odznaczający się głęboką wiarą i ufnością

10 Tenże, Dialog drugi 3, 8-10, [w:] tegoż, Pisma o św. Marcinie z Tours..., dz. cyt., s. 149.

11 Tenże, Chroniques, II, 45, 4, s. 330-332, SCh 441 - „Zresztą Lucyfer wtedy miał daleko inne przekonanie w Antiochii. Albowiem na tyle mocno potępił tych, którzy byli w Arimini, że także siebie oddzielił od wspólnoty z tymi, którzy owych przyjęli z powrotem po nawróceniu i uczynieniu pokuty. Nie odważyłbym się powiedzieć, czy słusznie czy niesłusznie postąpił. Paulinus i Rodanius umarli we Frygii, Hilary zmarł w szóstym roku po powrocie do ojczyzny”. Tekst oryginalny: „Ceterum Lucifer tum Antiochae longe diuersa sententia fuit. Nam in tantum eos, qui Arimini fuerant, condemnauit, ut se etiam ab eorum communione secreuerit, qui eos uel sub satisfactione uel paenitentia recepissent. Id recte an perperam constituerit dicere non ausim. Paulinus et Rhodanius in Phrygia defuncti, Hilarius sexto anno, postquam redierat, in patria obiit". 
w Boga. Sewer wyrażał przekonanie, że za każde przestępstwo należy się kara, stąd właśnie wynika ciągła potrzeba nawracania się. Sulpicjusz uważał, że oznaką nawrócenia jest pokora, a jego głównym motorem dręczące sumienie, lękające się słusznej kary za złe czyny. Trudno jednoznacznie ustalić, czym było dla Sulpicjusza Sewera nawrócenie: zmianą postępowania moralnego czy zmianą umysłu. Wydaje się, że większą uwagę zwracał na moralne postępowanie człowieka.

\section{Pokuta}

Sulpicjusz Sewer nauczał o głębokim sensie żalu i przebłagania Boga, które rodzą się ze świadomości grzechu. Uświadomienie sobie przez człowieka grzechu powoduje, że zasługuje on na karę. Tym, który karze za grzech, jest Bóg:

Tam przy wspólnym jęku i wzajemnym zawodzeniu upraszali pomocy Bożej; są świadomi, iż z powodu grzechów czy przestępstw wystarczająco zasłużyli na karę ze strony Boga i oby przynajmniej pozostałych oszczędził uwolniwszy z niewoli ${ }^{12}$.

Mnich akwitański zauważał, że nawoływanie do nawrócenia nie dodało wiary Niniwitom. Jednakże Bóg nie odmawia przebaczenia czyniącym pokutę, więc wynikałoby z tego, że pokuta wcale nie pomnaża wiary u pokutującego, lecz powoduje Boże przebaczenie wobec pokutujących:

W ten sposób grożące nieszczęście zostało odwrócone. Użalającemu się przed Bogiem Jonaszowi, że nie przybyło wiary [Niniwitom] na jego słowa, została dana odpowiedź, że nie można odmówić przebaczenia tym, którzy czynią pokutę ${ }^{13}$.

Sulpicjusz Sewer dostrzegał w swoim otoczeniu różnego rodzaju akty agresji i niesprawiedliwości, które wymagały od czyniących je nawrócenia. Sewer opisał komesa Awicjana, człowieka okrutnego, który zamierzał

12 Tenże, Chroniques, II, 15, 1, s. 260, SCh 441 - „Ibi communi gemitu permixtoque ululatu diuinum auxilium implorant: satis se Deo ob peccata uel crimina dedisse poenarum, reliquiis saltem seruitio nuper exemptis parceret".

13 Tenże, Chroniques, I, 47, 2, s. 208, SCh 441 - „Ita imminens malum auersum. Ionae apud Deum conquerenti, quod fides dictis non affuisset, responsum, paenitentibus ueniam negare non posse". 
w męczarniach wytracić jeńców. Jednakże temu sprzeciwił się św. Marcin. Z pomocą Marcinowi przyszedł anioł, który potrząsnął Awicjanem i oznajmił mu, że przyszedł do niego święty biskup. Na widok Marcina komes od razu wiedział, co ma czynić. Wyznał, że dość zniósł pokuty. Zapewne pokutą dla niego było przyznanie się przed służbą, że Marcin ma nad nim władzę. Rezultatem tego było zwołanie przez Awicjana swoich oficerów i wypuszczenie jeńców na wolność. Pokucie zatem towarzyszyło nawrócenie, czyli podjęcie konkretnego dobrego czynu ${ }^{14}$.

Sulpicjusz posłużył się historią z życia mnicha, aby ukazać wartość pokuty. Opowiadał o wilczycy, która żałowała kradzieży chleba i wstydziła się z powodu złego czynu. Zwierz pokutował i prosił o wybaczenie, pustelnik zaś jej wybaczył. Reakcją na przebaczenie była radość zwierzęcia i chętne dalsze służenie pustelnikowi. Jest to obraz pokuty, darowania winy, któremu musi towarzyszyć przyznanie się do błędu i prośba o wybaczenie. Następuje wówczas chęć naprawienia szkody, co wyraża się w dalszej służbie poszkodowanemu, wobec którego dopuszczono się krzywdy ${ }^{15}$.

Sulpicjusz Sewer uważał, że przebłaganie Boga za grzechy jest pokutą. Pokuta zaś stanowi naturalną konsekwencję wejścia na drogę nawrócenia. To właśnie poprzez nią grzesznik uzyskuje łaskę przebaczenia swoich grzechów i darowania win. Mnich akwitański uświadamiał czytelnikom, że pokucie towarzyszyć musi - oprócz przyznania się do winy - chęć zadośćuczynienia osobie, wobec której dopuściło się niesprawiedliwości.

Gdy Sulpicjusz Sewer wzywał swoich czytelników do nawrócenia, jego nauczanie podobne było do nauki o wybawieniu od śmierci fizycznej. Ważniejsze od narażenia się na wieczne potępienie jest, aby w życiu obecnym nie trwać w stanie niewoli. Dopiero gdy adwokat z Bordeaux zachęcał do czynienia pokuty, zwracał większą uwagę czytelnika na fakt, że za grzechy należy się słuszna kara. Sulpicjusz był człowiekiem pełnym chrześcijańskiego optymizmu i podkreślał miłosierdzie, które Bóg okazuje tyl-

14 Tenże, Dialog trzeci 4, 1-7, [w:] tegoż, Pisma o św. Marcinie z Tours..., dz. cyt., s. 170-171 (komes to dostojnik posiadający władzę administracyjno-wojskową).

15 Tenże, Dialog pierwszy 14, 2-7, [w:] tegoż, Pisma o św. Marcinie z Tours..., dz. cyt., s. 126. 
ko tym z nas, którzy przyznają się do popełnionych grzechów i podejmują odpowiednią pokutę.

Sulpicjusz Sewer nawet wówczas, gdy mówił o nawróceniu, dostrzegał nie tyle duchowy, wewnętrzny wymiar grzechu i narażanie się na wieczne potępienie, ile raczej pozostawanie w niewoli fizycznej. Ukazywał również potrzebę pokuty, która wyrasta ze świadomości grzechu. Przy omawianiu zagadnienia pokuty już wyraźniej kierował czytelnika ku Bogu, który karze za grzechy, ale i okazuje miłosierdzie w przebaczaniu, kiedy grzeszny człowiek pokutę podejmuje. Trzeba wyraźnie podkreślić, że Sulpicjusz jednoznacznie stwierdzał, że nawrócenie i pokuta są darem, czyli łaską od Boga. I mim że ciągle wspominał o mocy Chrystusa w czynach Marcina, to jednak można odnieść wrażenie, że dla Sulpicjusza Sewera na pierwszy plan wysuwała się postawa ascetyczna i zasługi moralne człowieka. Takie podejście jest teologicznie niebezpieczne, gdyż zaciemnia najważniejszą Osobę przy nawróceniu i pokucie człowieka - Syna Bożego Jezusa Chrystusa.

\section{Summary}

The Issue of Conversion and Penance in the Works of Sulpicius Severus

In his writings, Sulpicius Severus (360-420) urged his readers to repentance, so they would not expose themselves to eternal damnation, and therefore not remain in a state of slavery in this life. When a lawyer from Bordeaux encourages penance, He pays special attention to the fact that sin calls for the right punishment. Despite this, Sulpicius is a man full of Christian optimism and he emphasizes mercy that God only offers to those people who admit their sins and undertake an appropriate penance.

A striking feature of the Sulpicius message on conversion and penance is that a monk of Aquitaine continually shows the figure of St. Martin. Although he writes that the miracles of driving out demons are performed by the power of the cross of Christ, and that repentance is the work of Jesus' grace and steadfast faith and trust in God's help, it seems that for him the person of St. Martin is in the first place, not the Son of God Jesus Christ.

Keywords: repentance, forgiveness, penance, sin, humility, conscience, the grace of Christ, the monk

Słowa kluczowe: nawrócenie, przebaczenie, pokuta, grzech, pokora, sumienie, łaska Chrystusa, mnich 